Pacific Journal of Mathematics

A CONSTRUCTIVE PROOF OF THE INFINITE VERSION OF 


\title{
A CONSTRUCTIVE PROOF OF THE INFNIITE VERSION OF THE BELLUCE-KIRK THEOREM
}

\author{
TECK-ChEONG LiM
}

In [5], we proved the following infinite version of the Bellucekirk theorem [1]:

THEOREM 1 [5]. Let $K$ be a nonempty weakly compact convex subset of a Banach space and assume that $K$ possesses normal structure. Let $F$ be a commutative family of nonexpansive selfmappings of $K$. Then $\mathscr{F}$ has a common fixed point.

Fuchssteiner [3] recently proved an iteration theorem on partially ordered sets and derived several known fixed point theorems as consequences. This note is to respond to a final remark in [3]. We show that Theorem 1, indeed a more general one, can be proved without making use of the axiom of choice. We shall make use of the following theorem which can be proved constructively [2, Theorem I.2.5].

THEOREM 2 (Zermelo [7]). Let $f: E \rightarrow E$ have the property that $f(x) \geqq x$ where $(E, \leqq)$ is a nonempty partially ordered set with the additional properties:

(i) If $a \leqq b$ and $b \leqq a$ then $a=b$;

(ii) Every chain in $E$ has a least upper bound. Then $f$ has a fixed point in $E$.

Let $(X, d)$ be a metric space and let $\left\{B_{\alpha}: \alpha \in \Lambda\right\}$ be a decreasing net of bounded subsets of $X$, i.e., $\Lambda$ is a directed set and $B_{\alpha} \subseteq B_{\beta}$ if $\alpha \geqq \beta$. For each $x \in X$, let

$$
r(x)=\limsup _{a}\left\{d(x, y): y \in B_{\alpha}\right\}=\inf _{a} \sup \left\{d(x, y) y \in B_{\alpha}\right\}
$$

and

$$
r=\inf \{r(x): x \in X\} .
$$

The set $\{x \in X: \mathrm{r}(x)=r\}$ (the number $r$ ) will be called the asymptotic center (asymptotic radius) of $\left\{B_{\alpha}: \alpha \in \Lambda\right\}$ w.r.t. $X$. For a set $C$ in a topological space, $\operatorname{cl}(C)$ will denote its closure. A topological semigroup $S$ is said to be left reversible if any two nonempty closed right ideals of $S$ have a nonvoid intersection (cf. [4]). An action of a topological semigroup $S$ on $X$ is a mapping $\psi$ from $S \times X$ into $X$ denoted by $\psi(s, x)=s(x)$ such that $\left(s_{1} s_{2}\right)(x)=s_{1}\left(s_{2}(x)\right)$ for all $s_{1}, s_{2} \in S$, 
$x \in X$. The action is separately continuous if $\psi$ is continuous in each of the variables when the other is held fixed. An action of $S$ on $X$ is nonexpansive if for each $s \in S$, the mapping from $X$ into $X$ defined by $x \rightarrow s(x)$ is nonexpansive. If $S$ is a left reversible topological semigroup, and we put $s \geqq t$ if $s S \subseteq \operatorname{cl}(t S)$, then $(S, \geqq)$ becomes a directed set (see [4]).

The proof of the next lemma makes use of Theorem 1 in [6]. Note that this theorem was proved constructively.

Lemma 1. Let $K$ be defined as in Theorem 1 and let $S$ be a left reversible topological semigroup of nonexpansive, separately continuous actions on $K$. For each $s \in S$, let $W_{s}=\operatorname{cl}(s S(K))=$ $\operatorname{cl}\{s t(x): t \in S, x \in K\}$. If $K$ contains more than one point, then the family $W=\left\{W_{s}: s \in S\right\}$ is a decreasing net of subsets in $K$ whose asymptotic center in $K$ is a closed convex S-invariant proper subset of $K$.

Proof. If $s \geqq t$, then by making use of the continuity of $s \rightarrow s(x)$ for a fixed $x$, one can easily show that $s S(x) \subseteq \operatorname{cl}(t S(x))$ and hence $W_{s} \subseteq W_{t}$. Thus $\left\{W_{s}: s \in S\right\}$ forms a decreasing net of sets in $K$. By Theorem 1 in [6], the asymptotic center $C$ of $W$ w.r.t. $K$ is a closed convex proper subset of $K$. Assume that $r$ is the asymptotic radius and that $x$ is in the asymptotic center. If $\|x-y\| \leqq r+\varepsilon$ for every $y \in W_{t}$, then for each $s \in S,\|s(x)-z\| \leqq$ $r+\varepsilon$ for all $z \in W_{s t}$ by the nonexpansiveness of $s$. It follows that $C$ is an $S$-invariant set.

TheOREm 3 [6]. Let $K$ and $S$ be defined as in Lemma 1. Then $S$ has a common fixed point.

Proof. Let $X=\{Y \leqq K: \phi \neq Y=\overline{\operatorname{Co}}(Y), S(Y) \subseteq Y\}$. Order $X$ by putting $Y_{1} \leqq Y_{2}$ if and only if $Y_{1} \supseteqq Y_{2}$. (X, $\left.\leqq\right)$ satisfies the conditions in Theorem 2. For each $Y \in X$, let $f(Y)$ be the asymptotic center of $\left\{W_{s}: s \in S\right\}$ w.r.t. $Y$, where $W_{s}=\operatorname{cl}(s S(Y))$. Since $f(Y) \geqq Y$ for $Y \in X$, it follows from Theorem 2 that $f$ has fixed point, i.e., there exists $Y_{0} \in X$ such that $f\left(Y_{0}\right)=Y_{0}$. By Lemma $1, Y_{0}$ is a singleton. Therefore, $Y_{0}$ consists of one common fixed point of $S$.

REMARK. Obviously, Theorem 3 can also be proved by the iteration theorem in [3]. Theorem 1 is a special case of Theorem 3 when $S$ is a discrete commutative semigroup generated by $\mathscr{T}$. 


\section{REFERENCES}

1. L. P. Belluce and W. A. Kirk, Fixed-point theorems for families of contraction mappings, Pacific J. Math., 18 (1966), 213-217.

2. N. Dunford and T. Schwartz, Linear Operators, New York-London-Sydney, Interscience Publishers, (1958).

3. B. Fuchssteiner, Iterations and fixpoints, Pacific J. Math., 68 (1977), 73-80.

4. R. D. Holmes and A. T. Lau, Nonexpansive actions of topological semigroups and fixed points, J. London Math. Soc., (2) 5 (1972), 330-336.

5. T. C. Lim, A fixed-point theorem for families of nonexpansive mappings, Pacific J. Math., 53 (1974), 487-493.

6. - Characterizations of normal structure, Proc. Amer. Math. Soc., 43 (1974), 313-319.

7. E. Zermelo, Neuer Beweis fur die Moglichkeit einer Wohlordnung, Math. Ann., 65, (1908), 107-128.

Received March 13, 1978 and in revised form November 7, 1978.

UNIVERSITY OF CHICAGO

Chicago, IL 60637 



\title{
PACIFIC JOURNAL OF MATHEMATICS
}

\section{EDITORS}

\author{
DONALD BABBITT (Managing Editor) \\ University of California \\ Los Angeles, CA 90024 \\ HUGo ROSSI \\ University of Utah \\ Salt Lake City, UT 84112 \\ C. C. MOORE \\ University of California \\ Berkeley, CA 94720
}

J. DugundJI

Department of Mathematics

University of Southern California

Los Angeles, CA 90007

R. FinN and J. Milgram

Stanford University

Stanford, CA 94305

\section{ASSOCIATE EDITORS}
E. F. BECKENBACH
B. H. Neumann
F. WolF
K. YOSHIDA

\section{SUPPORTING INSTITUTIONS}

\author{
UNIVERSITY OF BRITISH COLUMBIA \\ CALIFORNIA INSTITUTE OF TECHNOLOGY \\ UNIVERSITY OF CALIFORNIA \\ MONTANA STATE UNIVERSITY \\ UNIVERSITY OF NEVADA, RENO \\ NEW MEXICO STATE UNIVERSITY \\ OREGON STATE UNIVERSITY \\ UNIVERSITY OF OREGON
}

UNIVERSITY OF SOUTHERN CALIFORNIA

STANFORD UNIVERSITY

UNIVERSITY OF HAWAII

UNIVERSITY OF TOKYO

UNIVERSITY OF UTAH

WASHINGTON STATE UNIVERSITY

UNIVERSITY OF WASHINGTON

The Supporting Institutions listed above contribute to the cost of publication of this Journal, but they are not owners or publishers and have no responsibility for its content or policies.

Mathematical papers intended for publication in the Pacific Journal of Mathematics should be in typed form or offset-reproduced, (not dittoed), double spaced with large margins. Please do not use built up fractions in the text of the manuscript. However, you may use them in the displayed equations. Underline Greek letters in red, German in green, and script in blue. The first paragraph or two must be capable of being used separately as a synopsis of the entire paper. Please propose a heading for the odd numbered pages of less than 35 characters. Manuscripts, in triplicate, may be sent to any one of the editors. Please classify according to the scheme of Math. Reviews, Index to Vol. 39. Supply name and address of author to whom proofs should be sent. All other communications should be addressed to the managing editor, or Elaine Barth, University of California, Los Angeles, California, 90024.

50 reprints to each author are provided free for each article, only if page charges have been substantially paid. Additional copies may be obtained at cost in multiples of 50 .

The Pacific Journal of Mathematics is issued monthly as of January 1966. Regular subscription rate: $\$ 72.00$ a year (6 Vols., 12 issues). Special rate: $\$ 36.00$ a year to individual members of supporting institutions.

Subscriptions, orders for numbers issued in the last three calendar years, and changes of address should be sent to Pacific Journal of Mathematics, P.O. Box 969, Carmel Valley, CA 93924, U.S.A. Older back numbers obtainable from Kraus Periodicals Co., Route 100, Millwood, NY 10546.

PUBLISHED BY PACIFIC JOURNAL OF MATHEMATICS, A NON-PROFIT CORPORATION

Printed at Kokusai Bunken Insatsusha (International Academic Printing Co., Ltd.). 8-8, 3-chome, Takadanobaba, Shinjuku-ku, Tokyo 160, Japan.

Copyright (C) 1979 by Pacific Journal of Mathematics Manufactured and first issued in Japan 


\section{Pacific Journal of Mathematics}

\section{Vol. 81, No. $2 \quad$ December, 1979}

Ersan Akyildiz, Vector fields and equivariant bundles ............... 283

Ehrhard Behrends, The centralizer of tensor products of Banach spaces ( $a$ function space representation) ......................... 291

Geoffrey R. Burton, Congruent sections of a convex body ............. 303

John Warnock Carlson, $H$-closed and countably compact extensions ...... 317

Robert Charles Carlson, Eigenfunction expansions for selfadjoint

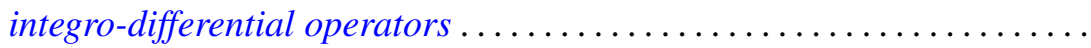

Robert Damiano, Coflat rings and modules.

Eric Karel van Douwen and Washek (Vaclav) Frantisek Pfeffer, Some properties of the Sorgenfrey line and related spaces ................

Uri Elias, Necessary conditions and sufficient conditions for disfocality and

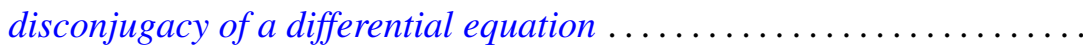

V. L. (Vagn Lundsgaard) Hansen, Polynomial covering spaces and homomorphisms into the braid groups .......................

Paul Hess, Dedekind's problem: monotone Boolean functions on the lattice

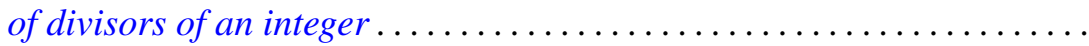

Alan Hopenwasser and David Royal Larson, The carrier space of a reflexive

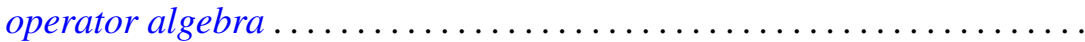

Kyung Bai Lee, Spaces in which compacta are uniformly regular $G_{\delta} \ldots \ldots$.

Claude Levesque, A class of fundamental units and some classes of

Jacobi-Perron algorithms in pure cubic fields...

Teck Cheong Lim, A constructive proof of the infinite version of the

Belluce-Kirk theorem ..........................

Dorothy Maharam and A. H. Stone, Borel boxes

Roger McCann, Asymptotically stable dynamical systems are linear

Peter A. McCoy, Approximation and harmonic continuation of axially symmetric potentials in $E^{3} \ldots \ldots \ldots \ldots \ldots \ldots \ldots$

Takahiko Nakazi, Extended weak-* Dirichlet algebras ....

Carl L. Prather, On the zeros of derivatives of balanced trigonometric polynomials ................................

Iain Raeburn, An implicit function theorem in Banach spaces...

Louis Jackson Ratliff, Jr., Two theorems on the prime divisors of zeros in completions of local domains...

Gloria Jean Tashjian, Cartesian-closed coreflective subcategories of

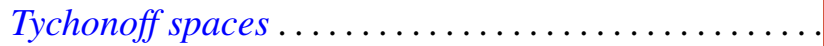

Stephen Edwin Wilson, Operators over regular maps.... . . 